\title{
FORMULASI DAN EVALUASI SEDIAAN LOSION DARI PERASAN BUAH BELIMBING MANIS (Averrhoa carambola L) SEBAGAI ANTIOKSIDAN
}

\author{
Athaillah $^{1^{*}, \text { Aisyah Maharani Hutauruk }}{ }^{2}$ \\ 1,2 Universitas Haji Sumatera Utara, Indonesia \\ Email: Atha8237@gmail.com \\ *corresponding author
}

\begin{abstract}
ABSTRAK
Buah belimbing manis (Averrhoa carambola L) memiliki banyak kandungan seperti Vitamin A, Kalium, serat, dan vitamin $\mathrm{C}$ sebagai antioksidan. Perasan buah belimbing manis dapat dibuat sebagai sedian farmasi dalam bentuk losion. Tujuan penelitian ini yaitu untuk mengetahui konsentrasi optimum perasan buah belimbing manis terhadap sifat fisik losion serta mengetahui aktivitas antioksidan sediaan losion belimbing manis. Penelitian ini merupakan penelitian eksperimental dengan tahapan penetapan kadar vitamin c buah belimbing manis dengan metode titrasi iodometri sebelum pembuatan losion. Pembuatan losion dengan 5 variasi konsentrasi peraasan belimbing manis $15,20,25,30,35 \%$ dan diuji stabilitas fisik sediaan losion dengan metode cycling test sebanyak 6 siklus yang meliputi $\mathrm{pH}$ dan daya sebar. Hasil penetapan kadar vitamin $\mathrm{C}$ pada perasan belimbing manis sebesar $1,232 \mathrm{mg} / \mathrm{ml}$. Hasil penelitian menunjukkan konsentrasi perasan buah belimbing manis tidak berpengaruh pada karakteristik fisik sediaan losion. Losion perasan buah belimbing manis memiliki aktivitas antioksidan dengan nilai sebesar 78,797 ppm dengan kategori kuat dan pembanding viamin $\mathrm{C}$ memiliki aktivitas antioksidan dengan nilai sebesar 3,238 ppm dengan kategoti sangat kuat. Konsentrasi perasan buah belimbing manis (Averrhoa carambola $\mathrm{L}$ ) tidak berpengaruh terhadap karakter sifat fisik sediaan losion buah belimbing manis yang meliputi organoleptik, homogenitas, $\mathrm{pH}$, dan tipe emulsi. Kecuali pada pengukuran daya sebar untuk uji cyling test terjadi peningkatan luas penyebaran tetapi tetap stabil pada suhu rendah dan aktivitas antioksidan pada sediaan losion belimbing manis pada formula 4 dengan tekstur losion yang paling baik memiliki aktivitas antioksidan dengan nilai sebesar 78,797 ppm dengan kategori kuat dan pembanding viamin $\mathrm{C}$ memiliki aktivitas antioksidan dengan nilai sebesar 3,238 ppm dengan kategoti sangat kuat.
\end{abstract}

Kata Kunci : Belimbing Manis, Kadar Vitamin C, Konsentrasi, Antioksidan

\section{ABSTRACT}

Sweet star fruits (Averrhoa carambola L) has alot of contents such as vitamin A, Potassium, fiber and vitamin $C$ as antioxidants. Sweet star fruits juice can be made as a pharmaceutical preperation in the form of a lotion. the purpose of the study was to determine the optimum concentrastion of sweet star fruit juice on the pysical propertise of the lotion on to determine the antioxidant activity of the prearation of sweet star fruit juice. This research is an experimental study with the stages of determining vitamin C levels of sweet star fruit by iodomentric titration 
method before making lotion. Making lotion with 5 variations of concentration of sweet star fruit juice 15,20,25,30,35\% and tested for physical stability of preparation with cycling test method as many as 6 cycling for observations were carried out each cycling which included $p H$ and dispersion of the preparation. The results of determination of vitamin $C$ levels in the juice of sweet star fruit are $1,232 \mathrm{mg} / \mathrm{ml}$. The results showed that the concentration of sweet star fruit juice had no effect on the physical characteristics of the lotion preparation. Sweet star fruit juice lotion has antioxidants activity with an value of 78,797 ppm, with a strong category snd a comparison of vitamin $C$ has value of 3,238 ppm very strong category. The concentration of sweet star fruit juice (Averrhoa carambola L) has no effect on the physical properties of sweet star fruit lotion preparation which include organoleptic, homogeneity, $\mathrm{pH}$, and type of emulsion, except for the dispersion measurement for the cycling test, there is an increase in the spread area but remains stable at low temperatures and antioxidant activity in the preparation of sweet star fruit lotion in formula 4 with the best lotion texture having antioxidant activity with an value of 78,797 ppm in the strong category and in comparison vitamin $C$ has antioxidant activity with an value of 3,238 ppm in the very strong category.

Keyword : Sweet Star Fruit, Vitamin C Levels, Concentration, Antioxidants

\section{PENDAHULUAN}

Belimbing manis (Averrhoa carambola $\mathrm{L}$ ) merupakan tanaman yang memiliki banyak kandungan berbagai zat gizi yang bermanfaat bagi tubuh, seperti vitamin A, Vitamin C, kalium dan serat (Puspaningtyas, 2013) . Vitamin C dikenal sebagai senyawa antioksidan yang berfungsi menetralisis radikal bebas di dalam tubuh yang mampu meningkatkan ketahanan tubuh. Selain itu, dapat melindungi kulit dari polusi udara dan sinar matahari (Kusumawati, 2008).

Dalam sari buah belimbing manis mengadung vitamin C sebanyak $35 \mathrm{mg}$ yang merupakan kandungan terbanyak diantra nilai gizi lainnya dalam sari buah belimbing manis tersebut. Vitamin $\mathrm{C}$ yang kadarnya tinggi dalam sari buah belimbing manis berfungsi sebagai antioksidan yang dapat diaplikasikan untuk melindungi dan melembabkan kulit dari efek serangan radikal bebas yang berasal dari polusi udara dan sinar matahari (Kusumawati, 2008).

Vitamin $\mathrm{C}$ memiliki peran penting yaitu pada sintesis kolagen dan memiliki efek fotoprotektif terhadap sinar UV. Vitamin C menetralisir ROS yaitu anion superoksida dan radikal hidroksil pada kompartemen aquous pada kulit (Chen,2012). Efek vitamin C pada sintesis kolagen adalah dengan menghambat biosintesis elastin dan mengurangi akumulasi elastin. Vitamin $\mathrm{C}$ mengurangi pembentukan pigmen pada kulit dengan menghambat tirosinase dan meningkatkan fungsi barier epidermis dengan merangsang produksi sfingolipid (Tiwari, 2001).

Antioksidan memiliki banyak manfaat untuk kesehatan kulit yaitu sebagai antipenuaan, perlindungan dari (Reactive Oxygen Species) ROS akibat stress oksidatif dan perlindungan dari UV (Lan et al.,2012). Antioksidan melindungi sel dari kerusakan kulit radikal bebas dengan mendonorkan satu elektron bebas ke radikal bebas atau menerima satu elektron yang tidak stabil sehingga menjadi stabil dan menghentikan reaksi serta mencegah kerusakan lipid, protein, dan DNA (Feller, 2010).

Suatu senyawa dikatakan sebagai antioksidan sangat kuat jika $\mathrm{IC}_{50}$ bernilai 50 ppm, berkemampuan kuat jika $\mathrm{IC}_{50}$ bernilai $50-100 \mathrm{ppm}$, berkemampuan sedang jika IC $_{50}$ bernilai 101-150 ppm dan berkemampuan lemah untuk IC $_{50}>150-200 \mathrm{ppm}$ (Utami, 2017). Hasil penelitian Ovielia (2020) menunjukkan bahwa sari buah belimbing manis 
memiliki aktivitas antioksidan kuat dengan nilai $\mathrm{IC}_{50}$ sebesar $60,45 \mu \mathrm{g} / \mathrm{mL}$ dengan kadar vitamin C sebesar 4,49 mg/ g.

Kulit sangat berpengaruh terhadap penampilan seseorang sehingga perlu dirawat, dipelihara, dan dijaga kesehatannya. Perawatan dan pemeliharaan akan menjadikan kulit terlihat sehat, terawat, serta senantiasa memancarkan kesegaran (Wirajayakusuma, 1998). Akan tetapi, jika tidak dirawat dan dipelihara dengan baik, maka akan menyebabkan kulit menjadi rusak. Proses perusakan kulit yang ditandai dengan munculnya keriput, sisik, kering, dan pecah-pecah banyak disebabkan oleh radikal bebas. Selain tampak kusam dan berkerut, kulit menjadi Lebih cepat tua dan muncul flek-flek hitam (Maysuhara, 2009).

Sebagai organ paling luar tubuh, kulit langsung terpapar dengan lingkungan prooksidan seperti radiasi ultraviolet, obat, polusi udara, dan asap rokok. Paparan lingkungan ini memicu pembentukan radikal bebas yang disebut juga reactive oxygen spesies (ROS) (Dreher dan Thiele, 2010). Selain disebabkan faktor eksogen, radikal bebas juga dibentuk secara alamiah melalui metabolisme sel fisiologis (Weber, 2009).

Pemanfaatan vitamin $\mathrm{C}$ dari buah belimbing manis dapat dibuat dalam bentuk sediaan. Bentuk sediaan yang sering digunakan adalah gel, krim, spray, dan losion. Losion dimaksudkan untuk penggunaan topikal yang sifat kecairannya memungkinkan untuk pemakain yang merata dan cepat pada permukaan kulit yang luas sehingga cepat kering, mudah dioleskan, mudah meyebar dan meninggalkan lapisan tipis dari komponen pada permukaan kulit (Jones, 2008).

Berdasarkan urain diatas maka akan dilakukan penelitian Tentang formulasi dan evaluasi sedian losion dari perasan buah belimbing manis (Averrhoa Carambola L) sebagai antioksidan.

\section{METODE PENELITIAN}

Penelitian ini merupakan jenis penelitian Eksperimental Laboratorium yaitu membuat formulasi dan evaluasi sediaan losion perasan belimbing manis (Averrhoa carambola L) sebagai antioksidan. Bahan yang digunakan adalah perasan buah belimbing manis, tween 80 , propilen glikol, paraffin liquid, setil alkohol, asam stearat, natrium benzoat, aquadest, iodin, amilum, vitamin C. Dengan alat adalah timbangan analitik, blender, saringan, gelas ukur, beaker gelas, statif dan klem, erlenmeyer, labu ukur, buret, pipet tetes, cawan porselen, mortir stemper, batang pengaduk, botol $500 \mathrm{ml}$, cawan petri, kaca preparat, stopwatch, $\mathrm{pH}$ universal, penangas air, dan kain kasa.

Pelaksanaan penelitian dilakukan mulai dari penyiapan sampel, sampel buah belimbing manis diambil di desa pasar Sorkam Barat Kecamatan Sorkam Barat Kabupaten Tapanuli Tengah. Buah belimbing manis dibersihkan, dipotongpotong menjadi bagian kecil, dan dipisahkan dari bijinya. Selanjutnya diblender dan disaring sehingga diperoleh perasan buahnya.

Perasan yang diperoleh diuji penetapan kadar vitamin $\mathrm{C}$ dengan dengan metode titrasi iodometri menggunakan larutan iodium dan larutan indikator amilum sampai berwarna biru. Tahap selanjutnya adalah pembuatan sediaan losion seperti ditunjukkan pada Tabel 1. 
Tabel 1. Formula sediaan losion perasan buah belimbing manis

\begin{tabular}{lllccccc}
\hline \multirow{2}{*}{ Formula } & \multicolumn{7}{c}{ Jumlah bahan } \\
\cline { 2 - 6 } & \multicolumn{1}{c}{ I } & II & III & IV & V & Satuan \\
\hline Perasan belimbing manis & 15 & 20 & 25 & 30 & 35 & $\mathrm{v} / \mathrm{v}$ \\
Propilen Glikol & 15 & 15 & 15 & 15 & 15 & $\mathrm{v} / \mathrm{v}$ \\
Tween 80 & 10 & 10 & 10 & 10 & 10 & $\mathrm{v} / \mathrm{v}$ \\
Paraffin Liquid & 10 & 10 & 10 & 10 & 10 & $\mathrm{v} / \mathrm{v}$ \\
Setil alkohol & 8 & 8 & 8 & 8 & 8 & $\mathrm{~b} / \mathrm{v}$ \\
Asam stearat & 6 & 6 & 6 & 6 & 6 & $\mathrm{~b} / \mathrm{v}$ \\
Natrium benzoat & 0,3 & 0,3 & 0,3 & 0,3 & 0,3 & $\mathrm{~b} / \mathrm{v}$ \\
Aquadest Ad & 100 & 100 & 100 & 100 & 100 & $\mathrm{v} / \mathrm{v}$ \\
\hline
\end{tabular}

Formula sediaan losion dilakukan uji sifat fisik yang meliputi : uji organoleptik, uji homogenitas, uji $\mathrm{pH}$, uji daya sebar, uji tipe emulsi, uji stabilitas dan uji iritasi. Setelah itu dilakukan uji aktivitas antioksidan.

\section{HASIL DAN PEMBAHASAN}

\section{Hasil Penetapan Kadar Vitamin C}

Penetapan kadar vitamin $\mathrm{C}$ menggunakan sampel perasan buah belimbing manis. Perlakuan pertama adalah pembuatan filtrat dari perasan belimbing yang disaring. Filtrat tersebut diencerkan kedalam labu ukur $50 \mathrm{ml}$. Selanjutnya sampel diambil $10 \mathrm{ml}$ dan dimasukkan kedalam erlenmeyer dan ditambahkan indikator amilum 1\%, setelah itu dititrasi dengan larutan iodin $0,01 \mathrm{M}$, proses titrasi dilakukan sampai mencapai titik akhir yaitu perubahan warna yaitu dari larutan bening menjadi larutan biru. Berdasarkan hasil penelitian kadar vitamin $C$ pada perasan buah belimbing manis adalah $1,232 \mathrm{mg} / \mathrm{ml}$. Hasil pengujian ditunjukkan pada Gambar 1. Pada penelitian (Oveilia, 2020) sari buah belimbing manis memiliki kadar vitamin $\mathrm{C}$ sebesar $4,49 \mathrm{mg} / \mathrm{g}$.

Analisis kadar vitamin $\mathrm{C}$ dalam sampel ini menggunakan metode titrasi iodometri. Titrasi ini merupakan titrasi berdasarkan reaksi redoks yang menggunakan larutan beku Iodin untuk mengoksidasi analatnya. Iod merupakan oksidator yang tidak terlalu kuat, sehingga hanya zat-zat yang merupakan reduktor yang cukup dapat dititrasi. Indikator yang digunakan adalah amilum, dengan perubahan dari tidak berwarna menjadi berwarna biru. Sedangkan vitamin $\mathrm{C}$ dengan iod akan membentuk ikatan dengan atom $\mathrm{C}$ nomor 2 dan 3 sehingga ikatan rangkap hilang (Harjadi,1990). 


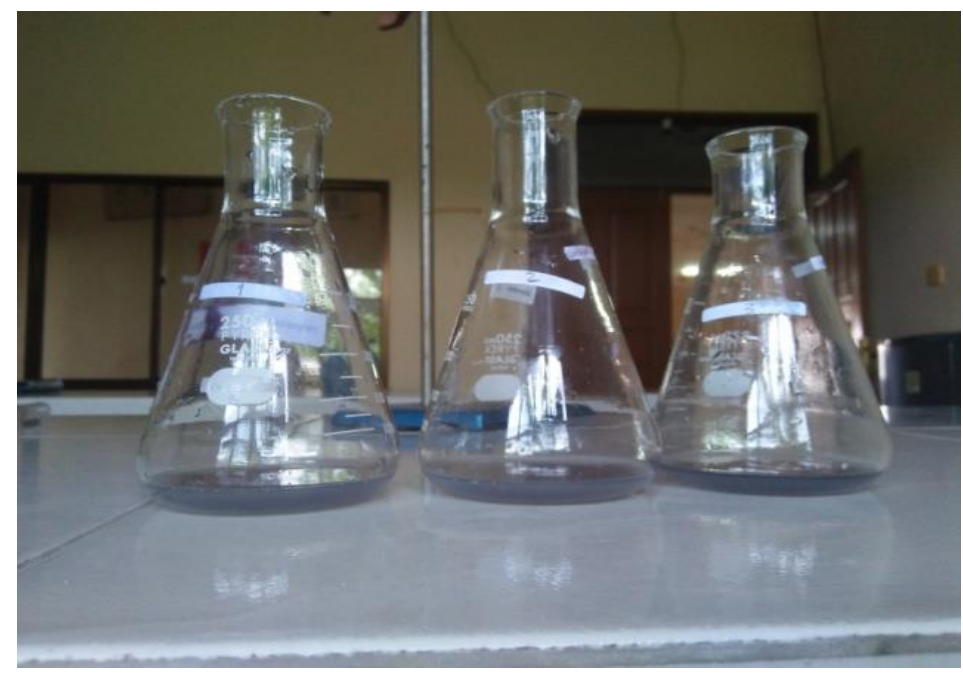

Gambar 1. Hasil Titrasi

\section{Hasil Evaluasi Formula Sediaan Losion}

a. Hasil Uji Organoleptis

Pengujian organoleptik dilakukan secara visual dengan mengamati sediaan losion perasan buah belimbing manis yang meliputi bentuk, bau, warna. Hasil pengujian ditunjukkan pada Tabel 2.

Tabel 2. Hasil uji organoleptis

\begin{tabular}{|c|c|c|c|c|c|}
\hline \multirow{2}{*}{ Parameter } & \multicolumn{5}{|c|}{ Hasil Pengamatan } \\
\hline & F1 & F2 & F3 & F4 & F5 \\
\hline & Putih & Putih & Putih & Putih & Putih \\
\hline Warna & kekuningan & kekuningan & Kekuningan & Kekuningan & Kekuningan \\
\hline Aroma & Bau Khas & Bau Khas & Bau Khas & Bau Khas & Bau Khas \\
\hline Bentuk & Massa Losion & $\begin{array}{l}\text { Massa } \\
\text { Losion }\end{array}$ & Massa Losion & Massa Losion & Massa Losion \\
\hline Konsistensi & Kental & Kental & Kental & $\begin{array}{l}\text { Kurang } \\
\text { Kental }\end{array}$ & Sedikit Encer \\
\hline
\end{tabular}

Berdasarkan tabel 2 losion belimbing manis berbentuk massa losion berwarna putih kekuningan. Warna kekuningan dihasilkan dari perasan buah belimbing manis itu sendiri dan berbau khas serta konsistensi losion relatif kental. Pada saat diaplikasikan ke kulit terasa lembut. Hasil uji menyatakan semua formulasi menghasilkan organoleptis yang sama. Namun pada konsistensi losion terdapat perbedaan pada formula 4 dan 5 tekstur losion nya relatif encer. Hal ini di karenakan kelima formula menggunakan komponen bahan dan cara pembuatan yang sama. sediaan losion belimbing manis dari kelima formula dapat dilihat pada gambar 2 . 

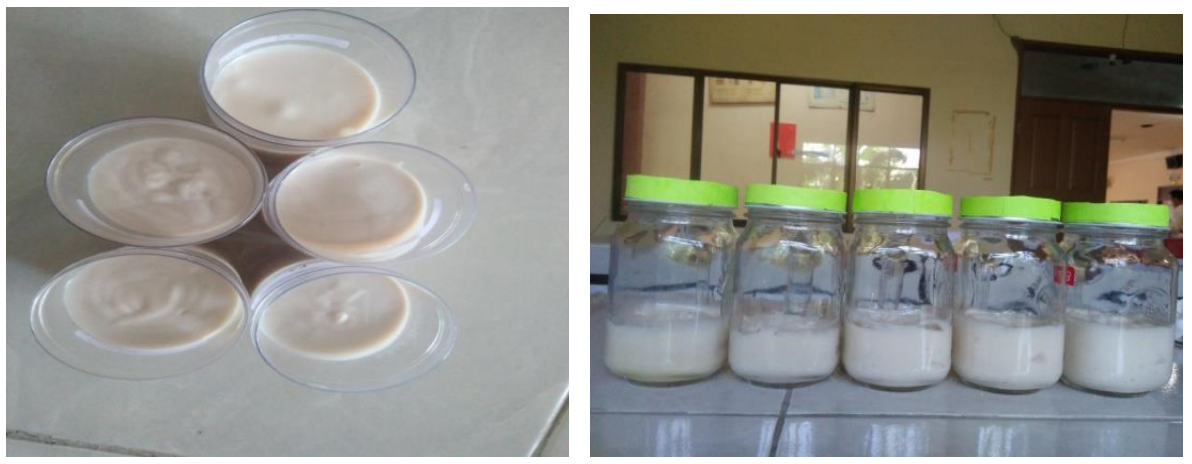

Gambar 2. Losion Belimbing Manis

\section{b. Hasil Uji Homogenitas}

Uji homogenitas dilakukan dengan cara sampel losion dioleskan pada kaca preparat, sediaan harus menunjukkan susunan yang homogen dan tidak terlihat adanya butiran kasar. Tujuan Uji homogenitas dilakukan untuk mengetahui tercampur atau tidaknya bahan-bahan sediaan losion. Hasil uji homogenitas diperoleh hasil homogen untuk semua formula seperti ditunjukkan pada Gambar 2 dan Gambar 3.

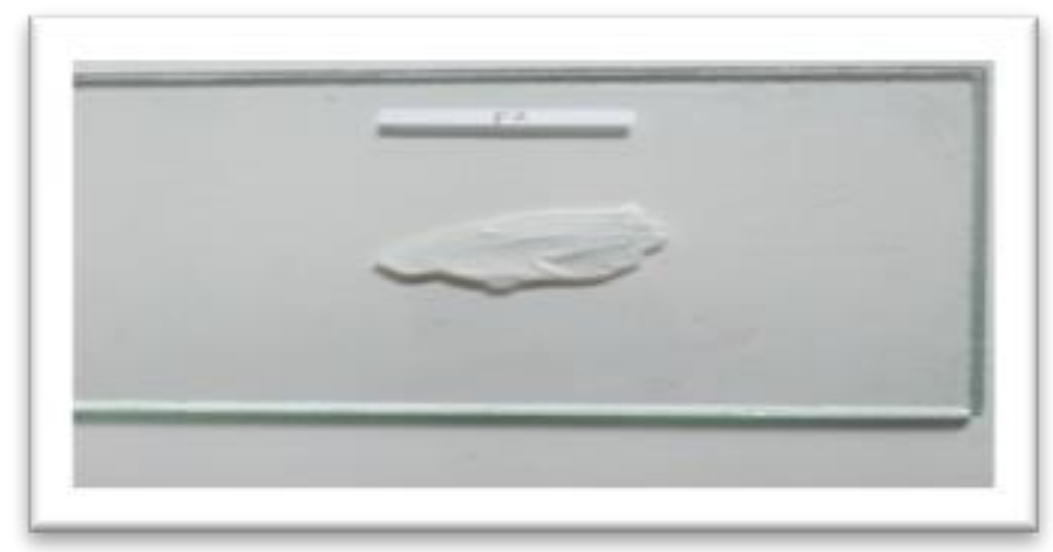

Gambar 3. Hasil Uji Homogenitas

Berdasarkan hasil penelitian yang dilakukan oleh astute et al (2017) menyatakan bahwa peningkatan konsentrasi perasan buah belimbing manis tidak mempengaruhi homogenitas sediaan losion belimbing manis. hal ini dikarenakan semua bahan tercampur secara homogen dengan tidak adanya granul-granul kasar pada permukaan kaca preparat.

\section{c. Hasil Uji pH}

Pengujian $\mathrm{pH}$ bertujuan untuk mengetahui kestabilan suatu sediaan dan untuk mengetahui derajat keasaman atau kebasaan yang dimiliki suatu sediaan. Sehingga sediaan aman untuk digunakan pada kulit manusia. Hasil uji $\mathrm{pH}$ terhadap formula sediaan losion diperoleh nilai $\mathrm{pH}$ yang sama yaitu 5. Hasil ini menunjukkan bahwa formula sediaan losion memenuhi batas $\mathrm{pH}$ fisiologis kulit. Hal ini sesuai dengan Standar Nasional Indonesia (SNI) tahun 1996 Nomor (16-4399-1996) menjelaskan bahwa pH kulit manusia berkisar 4,5-8.

Barel, dkk (2001) menjelaskan bahwa apabila sediaan lotion memiliki nilai $\mathrm{pH}$ di atas fisiologis kulit, maka sediaan tersebut akan bersifat terlalu basa yang dapat menyebabkan 
kulit menjadi kering, sedangkan jika nilai $\mathrm{pH}$ di bawah fisiologis kulit maka akan bersifat terlalu asam yang dapat menyebabkan terjadinya iritasi kulit (Barel et al., 2001).

\section{d. Hasil Uji Daya Sebar}

Pengamatan daya sebar dilakukan untuk mengetahui kemampuan menyebar sediaan saat diaplikasikan pada kulit, dan sediaan yang baik adalah sediaan yang mudah menyebar pada kulit tanpa menggunakan tekanan yang besar.

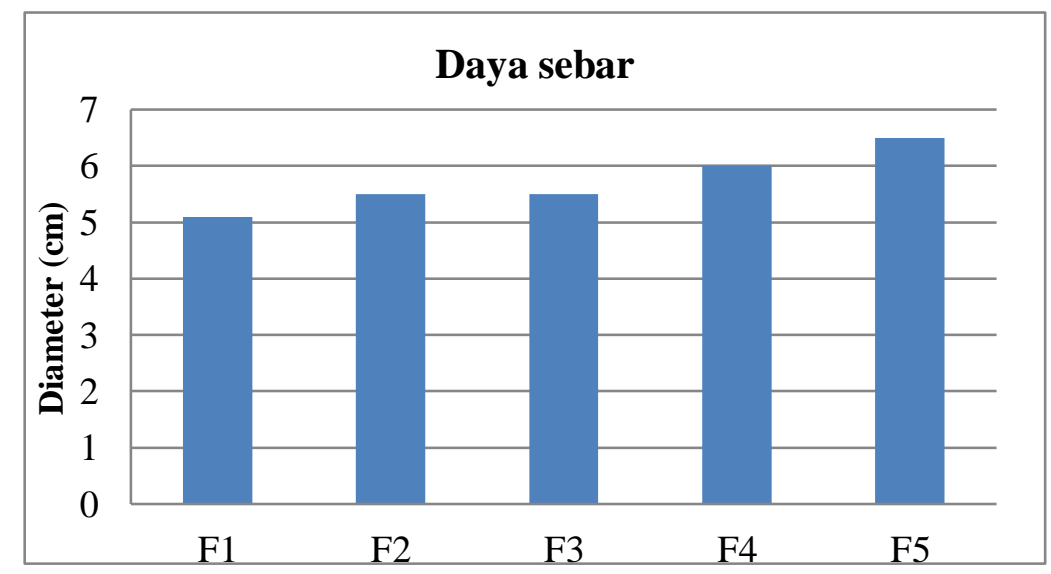

Gambar 4. Hasil Pengukuran Daya Sebar

Berdasarkan Gambar 4 menunjukkan bahwa daya sebar untuk formula sediaan losion memiliki diameter sebar antara 5-6,5 cm. Daya sebar dilakukan untuk menjamin bahwa sediaan semisolid mampu menyebar dengan mudah tanpa tekanan yang berarti sehingga mudah dioleskan tanpa menimbulkan rasa sakit saat dioleskan untuk menjamin kenyamanan pengguna.

Semakin besar daya sebar sediaan menunjukkan kemampuan zat aktif untuk menyebar dan kontak dengan kulit semakin dekat. Hasil uji daya sebar yang didapat yaitu pada F1 $(5,1 \mathrm{~cm})$, pada F2 $(5,5 \mathrm{~cm})$,pada F3 $(5,5 \mathrm{~cm}), \mathrm{F} 4(6 \mathrm{~cm})$ dan F5 $(6,5 \mathrm{~cm})$. Hasil uji daya sebar pada formula sediaan losion ini memenuhi SNI 06-2588 yaitu sebesar 5-7 $\mathrm{cm}$.

\section{e. Hasil Uji Tipe Emulsi}

Uji tipe emulsi dilakukan dengan menggunakan metode pengenceran, Pengujian tipe emulsi losion belimbing manis bertujuan untuk mengetahui losion mempunyai tipe minyak dalam air (M/A) atau air dalam minyak (A/M).

Berdasarkan uji yang dilakukan terhadap semua formula sediaan losion diperoleh tipe emulsinya adalah air dalam minyak (A/M). Hal ini menunjukkan bahwa peningkatan konsentrasi tidak memberikan pengaruh pada tipe emulsi losion perasan buah belimbing manis. Anita (2012) menjelaskan bahwa hal ini di karenakan losion tidak tercampur sempurna dengan air. Dapat juga terjadi karena zat aktif dan pelarut yang digunakan adalah air. Hasil tipe emulsi ditunjukkan pada Gambar 5. 


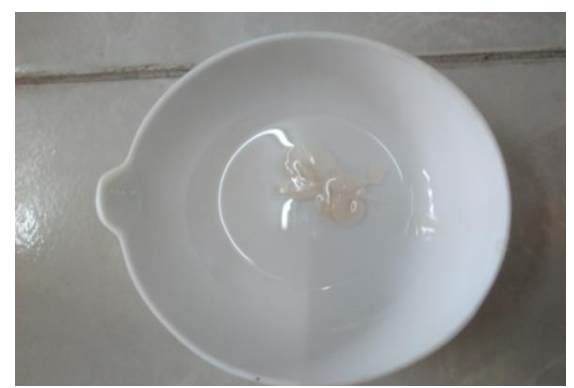

Gambar 5. Uji Tipe Emulsi

f. Hasil Uji Stabilitas pada Uji pH dan Uji daya sebar

Uji stabilitas Pada uji $\mathrm{pH}$ dan daya sebar dilakukan dengan metode cycling test. Yang disimpan pada suhu $4^{\circ} \pm 2^{\circ} \mathrm{C}$ selama 6 siklus. Tujuannya adalah untuk mengetahui kestabilan losion perasan belimbing selama 6 hari.

1. Hasil Uji pH pada cycling Test

Hasil uji pH selama cycling test dapat dilihat pada Tabel 3.

Tabel 3. Hasil Uji pH Pada Cycling Test

\begin{tabular}{lllllll}
\hline \multirow{2}{*}{ Formula } & \multicolumn{6}{l}{ Hasil Pengamatan Uji pH } \\
\cline { 2 - 7 } & H1 & H2 & H3 & H4 & H5 & H6 \\
\hline F1 & 5 & 5 & 5 & 5 & 5 & 5 \\
F2 & 5 & 5 & 5 & 5 & 5 & 5 \\
F3 & 5 & 5 & 5 & 5 & 5 & 5 \\
F4 & 5 & 5 & 5 & 5 & 5 & 5 \\
F5 & 5 & 5 & 5 & 5 & 5 & 5 \\
\hline
\end{tabular}

Berdasarkan Tabel 3 dapat dilihat bahwa hasil uji $\mathrm{pH}$ pada cylcing test tidak mengalami pergeseran $\mathrm{pH}$ dan stabil pada suhu rendah. Selain itu juga tidak terjadi pemisahan fase pada sediaan losion. Sari et al (2018) menjelaskan bahwa uji stabilitas dengan metode frezeer thaw cycling test dilakukan untuk mengetahui apakah sediaan mengalami pemisahan fase setelah proses penyimpanan.

2. Hasil Uji daya sebar pada cycling test

Hasil uji daya sebar selama cycling test dapat dilihat pada Gambar 6.

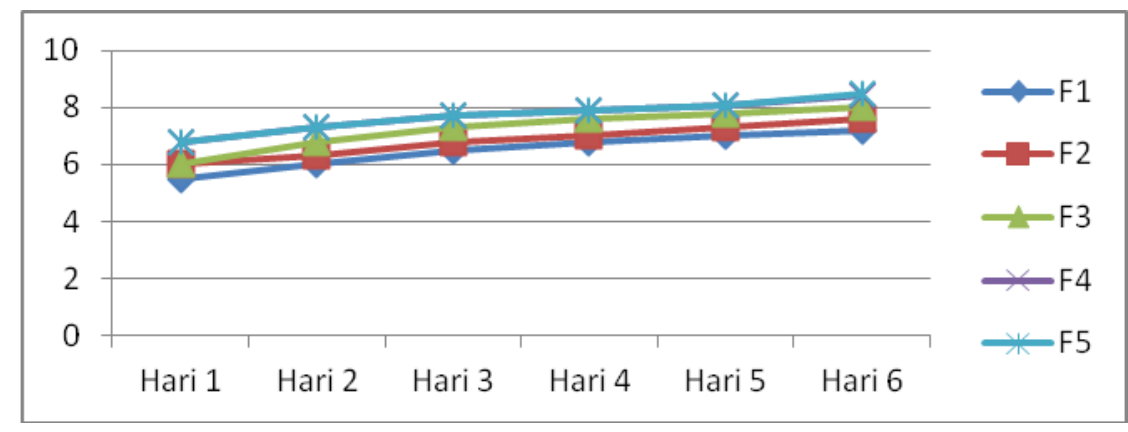

Gambar 6. Hasil Pengukuran daya sebar pada Cycling Test 
Berdasarkan grafik diatas diameter daya sebar losion belimbing manis mengalami peningkatan daya sebar pada $\mathrm{F} 1$ hari $1-6$ yaitu $5,5-7,2 \mathrm{~cm}$ pada $\mathrm{F} 26-7,6 \mathrm{~cm}$ pada $\mathrm{F} 36-8$ cm pada F4 6,8-8,4 cm dan F5 6,8-8,5 cm. tetapi tidak mengalami perubahan bentuk losion. hal ini bisa dikatakan daya sebar losion belimbing manis masih tetap stabil pada suhu rendah

\section{g. Hasil Uji Iritasi}

Uji iritasi sediaan losion dilakukan dengan menggunakan metode uji tempel tertutup terhadap 4 orang panelis selama 24 jam dengan cara mengoleskan sediaan losion pada kulit panelis yang normal. Uji iritasi dilakukan untuk mengetahui apakah sediaan tersebut menghasilkan gejala-gejala iritas yaitu kemerahan pada kulit, gatal-gatal serta bengkak pada kulit panelis. Iskandar beni et al (2019) menjelaskan bahwa gejala iritasi ditandai munculnya bintik-bintik merah, gatal-gatal, serta bengkak pada kulit. Hasil pengujian ditunjukkan pada Tabel 4 dan Gambar 7 .

Berdasarkan Tabel 4 diperoleh hasil X (Tidak terjadi reaksi alergi) untuk semua formula sediaan losion yang diuji terhadap 4 orang panelis. Hasil secara visual juga dapat dilihat pada Gambar 7 yaitu tidak adanya gejala iritasi yang dihasilkan pada bagian kuit yang diuji. Hal ini dikarenakan formula sediaan losion yang digunakan memakai zat aktif yang alami dan $\mathrm{pH}$ yang sesuai standar. Sehingga formula sediaan losion perasan belimbing manis (Averrhoa carambola $\mathrm{L}$ ) aman digunakan atau diaplikasikan pada kulit manusia.

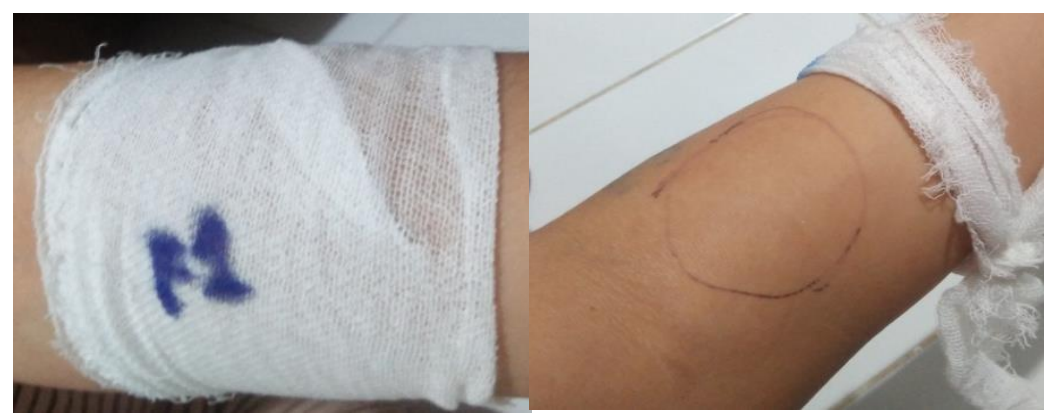

Gambar 7. Uji Iritasi 
Tabel 4. Hasil Uji Iritasi

\begin{tabular}{|c|c|c|c|c|}
\hline Formula & Sukarelawan & $\begin{array}{c}\text { Kemerahan } \\
\text { Pada Kulit }\end{array}$ & $\begin{array}{c}\text { Gatal Pada } \\
\text { Kulit }\end{array}$ & $\begin{array}{c}\text { Bengkak Pada } \\
\text { kulit }\end{array}$ \\
\hline \multirow{4}{*}{$\mathrm{F} 1$} & I & $\mathrm{X}$ & $\mathrm{X}$ & $\mathrm{X}$ \\
\hline & II & $\mathrm{X}$ & $X$ & $\mathrm{X}$ \\
\hline & III & $X$ & $X$ & $\mathrm{X}$ \\
\hline & IV & $X$ & $X$ & $X$ \\
\hline \multirow{4}{*}{$\mathrm{F} 2$} & $\mathrm{I}$ & $\mathrm{X}$ & $\mathrm{X}$ & $\mathrm{X}$ \\
\hline & II & $X$ & $X$ & $X$ \\
\hline & III & $X$ & $X$ & $X$ \\
\hline & IV & $\mathrm{X}$ & $\mathrm{X}$ & $\mathrm{X}$ \\
\hline \multirow{4}{*}{ F3 } & $\mathrm{I}$ & $\mathrm{X}$ & $\mathrm{X}$ & $\mathrm{X}$ \\
\hline & II & $\mathrm{X}$ & $\mathrm{X}$ & $\mathrm{X}$ \\
\hline & III & $\mathrm{X}$ & $X$ & $\mathrm{X}$ \\
\hline & IV & $\mathrm{X}$ & $X$ & $\mathrm{X}$ \\
\hline \multirow{4}{*}{$\mathrm{F} 4$} & $\mathrm{I}$ & $\mathrm{X}$ & $\mathrm{X}$ & $\mathrm{X}$ \\
\hline & II & $X$ & $X$ & $X$ \\
\hline & III & $\mathrm{X}$ & $X$ & $X$ \\
\hline & IV & $X$ & $X$ & X \\
\hline \multirow{4}{*}{ F5 } & I & $\mathrm{X}$ & $\mathrm{X}$ & $\mathrm{X}$ \\
\hline & II & $X$ & $X$ & $X$ \\
\hline & III & $\mathrm{X}$ & $X$ & $\mathrm{X}$ \\
\hline & IV & $\mathrm{X}$ & $X$ & $\mathrm{X}$ \\
\hline
\end{tabular}

\section{Keterangan :}

X $\quad$ Tidak Terjadi Reaksi Alergi
$\sqrt{ } \quad:$ Terjadi Reaksi Alergi

\section{Hasil Uji Aktivitas Antioksidan}

Pengujian aktivitas antioksidan pada sediaan losion belimbing manis dilakukan pada Formula 4 dengan tekstur losion yang paling baik dengan uji pembanding vitamin $\mathrm{C}$ menggunakan metode DPPH dengan alat spektrofotometri UV-Vis. Aktivitas antioksidan diukur dengan menghitung jumlah pengurangan intensitas warna ungu DPPH yang sebanding dengan pengurangan konsentrasi larutan DPPH. Hal ini terjadi karena adanya antara molekul DPPH dengan atom hidrogen yang dilepaskan satu molekul komponen sampel sehingga terbentuk senyawa DPPH dan menyebakan terjadinya peluruhan warna DPPH dari Ungu menjadi kuning (Mu'nisa, 2012).

Tebel 5. Kategori nilai $\mathrm{IC}_{50}$ sebagai antioksidan

\begin{tabular}{|c|c|c|}
\hline No. & Kategori & Konsentrasi (ppm) \\
\hline 1. & Sangat Kuat & $<50$ \\
\hline 2. & Kuat & $50-100$ \\
\hline 3. & Sedang & $101-150$ \\
\hline 4. & Lemah & $151-200$ \\
\hline
\end{tabular}

Sumber : Utami, (2017) 
Berdasarkan penelitian (Utami, 2017) kategori nilai belimbing manis memiliki aktivitas antioksidan dengan nilai IC $_{50}$ sebesar 78,797 ppm dengan kategori kuat sedangkan pembanding vitamin $\mathrm{C}$ memiliki nilai IC $_{50}$ sebesar 3,238 ppm dengan kategori sangat kuat. Dengan ini sesuai penelitian Oveilia (2020) dapat disimpulkan bahwa losion belimbing manis telah terbukti memiliki aktivitas antioksidan dengan kategori kuat. Konsentrasi yang digunakan pada pengujian aktivitas antioksidan dapat di lihat pada gambar 17.

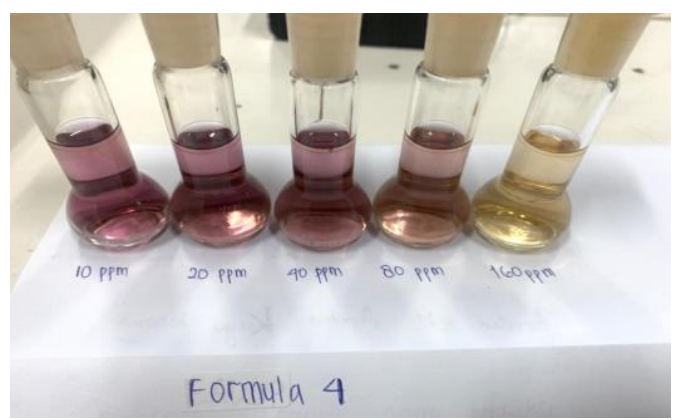

Gambar 18. Hasil Uji Aktivitas Antioksida

\section{KESIMPULAN}

Perasan buah belimbing manis (Averrhoa carambola L) memiliki kadar vitamin C sebesar $1,232 \mathrm{mg} / \mathrm{ml}$ dan konsentrasi perasan buah belimbing manis tidak berpengaruh terhadap karakter sifat fisik sediaan losion buah belimbing manis yang meliputi organoleptis, homogenitas, $\mathrm{pH}$, dan tipe emulsi . Kecuali pada pengukuran daya sebar untuk uji cycling test terjadi peningkatan luas penyebaran tetapi tetap stabil pada suhu rendah. Aktivitas antioksidan pada sediaan losion belimbing manis (Averrhoa carambola L) pada formula 4 dengan tekstur losion yang paling baik memiliki aktivitas antioksidan dengan nilai $\mathrm{IC}_{50}$ sebesar $78,797 \mathrm{ppm}$ dengan kategori kuat dan pada pembanding vitamin $\mathrm{C}$ mempunyai aktivitas antioksidan dengan nilai $\mathrm{IC}_{50}$ sebesar 3,238 ppm dengan kategori sangat kuat.

\section{DAFTAR PUSTAKA}

Anasthasia Pujiastuti, Monica Kristiani, 2019. Formulasi dan Uji Stabilitas Mekanik Hand Body Lotion Sari Buah Tomat (Licopercison esculentum Mill) sebagafi antioksidan. Jurnal Farmasi. Politeknik Katolik Mangunwijaya Semarang

Astuti, D. P., Husni, P., \& Hartono , K. 2017. "Formulasi dan uji stabilitas fisik sediaan gel antiseptic tangan minyak atsiri bunga lavender ( Lapandula angustipolia Miller)". Jurnal Farmaka, 15(1), 176-184.

Badan Standarisasi Nasional, 1996, Sediaan Tabir Surya, Badan Standarisasi Nasional , Jakarta. SNI 16-4399-1996.

Barel, A.O., Paye, M., Maibach, H.I.,2001, Handbook of Cosmetic Science and Technology, Marcel Dekker, Inc., New York 
Chen L. The role of antioxidant in photoprotector: a critical review. J Am Acad Dermatol. 2012; 67(5): 1013-24.

Dreher F, Thiele J. Antioxidants. In: Baran R, Maibach HI, editors. Textbook of Cosmetic Dermatology. 4 th ed. London: Taylor and Francis; 2010. p. 115-22.

Fuller BB. Antioxidant and anti inflammatories. In: Draelos ZD editor. Cosmetic Dermatology Product and Prosedure. Oxford: Willey Blackwell; 2010. pp. 281-4.

Iskandar, Benni et al. 2019. "Evaluasi sifat fisik dan uji kelembaban sediaan losion yang dijual secara online shope", Jurnal Farmasi. Sekolah tinggi ilmu farmasi Riau.

Jones, D. (2008). FASTrack Pharmaceutics-Dosage Form AND Design. Pharmaceutical Press. USA, P. 86

Kusumawati, P.R. 2008. Pengaruh Penambahan Asam Sitrat dan Pewarna Alami Kayu Secang (Caesalpinia Sappan L.) Terhadap Stabilitas Warna Sari Buah Belimbing Manis (Averrhoa Carambola L.). Skripsi. Institut Pertanian Bogor.

Lan, Z., Liu, J., Chen, L., Fu, Q., Luo, J., Qu, R., Ma, S. 2012. "Danggui- Shaoyao-San ameliorates cognition deficits and attenuates oxidative stress-related neuronal apoptosis in d-galactosa-induced senescent misce". Journal of Etnopharmacology. 141(1), 386-395.

Maysuhara, S. 2009. Rahasia Cantik, Sehat dan Awet Muda. Edisi I. Yogyakarta: Pustaka Panasea

Mu'nisa, A., 2012., Analisis Kadar Likopen dan Uji Aktivitas Antioksidan Pada Tomat Asal Sulawesi Selatan, Jurnal Bionature, Volume 13, Nomor 1, hlm.62-66

Ovielia, Ayu Fatmaningtyas, 2020. Aktivitas Antioksidan Sari Buah Belimbing Manis (Averrhoa Carambola L) Dan Penetapan Kadar Vitamin C. Skripsi Thesis, Universitas Wahid Hasyim.

Puspaningtyas, Desty dan Ervira. 2013. The Miracle Of Fruits. Jakarta: Aromedia

Sari Anita Puspita, 2012., Pengaruh Emulgator Terhadap Stabilitas Fisik Lotion Minyak Nilam (Patchouli oil) Dan Uji Efek Anti-Nyamuk. Skripsi, Universitas Islam Negeri Alauddin makasar.

Tiwari AK. Imbalance in antioxidant defence and human diseases: multiple approach of natural antioxidants therapy. Curr Sci. 2001; 81(9): 1179-87.

Weber, SU. Antioxidants. In: Maibach HI, editor. Handbook of Cosmetics Science and Technology. 3rd ed. New York: Informa Healthcare; 2009. p. 301- 10.

Wirajayakusuma, Hembing. 1998. Hidup Sehat Cara Hembing. Cetakan ke-1. Edisi Ke15. Jakarta : PT. Elex Media Komputindo. Gramedia. 